\title{
Pericardioperitoneal Canal
}

National Cancer Institute

\section{Source}

National Cancer Institute. Pericardioperitoneal Canal. NCI Thesaurus. Code C34246.

Two thin canals, located on either side of the foregut and dorsal to the septum

transversum, that connect the thoracic and abdominal portions of the intraembryonic coelom, which subsequently forms the pleural cavities. 